\title{
DIOCTAHEDRAL SMECTITE MEMPERPENDEK DURASI DIARE KRONIK PADA ANAK
}

\author{
Satrio Wibowo ${ }^{\star 凶}$, Putri Primawardani*
}

\begin{abstract}
Abstrak
Diare kronik merupakan salah satu masalah saluran cerna tersering pada anak yang dialami oleh sekitar 3-20\% anak dari seluruh episode diare pada balita adalah diare khronis. Diare kronik ditandai dengan diare yang berlangsung lebih dari 2 minggu. Dioctahedral smectite merupakan adsorben yang dipakai luas dalam pengobatan diare pada anak. la mampu mengabsorbsi toksin, bakteri dan rotavirus, serta mencegah perlekatannya pada membran usus. Dioctahedral smectite juga bermanfaat memperkuat barrier mukosa usus dan ketika tidak ada mukus mencegah kerusakan mukosa usus. Penelitan ini bertujuan untuk menelib manfaat dioctahedral smectite dalam memperpendek masa diare pada anak dengan diare khronis. Seratus empat puluh lima dari anak dengan diare kronis yang dirawat di RS Dr. Saiful Anwar Malang pada bulan Januari 2012 - Desember 2016 dievaluasi dalam penelitan ini. Pasien dengan darah dan parasit pada hasil feses lengkap dikeluarkan dari penelitan. Terdapat 45 pasien yang memenuhi kriteria inklusi. Pasien dibedakan menjadi 2 kelompok, yang mendapatkan dioctahedral smectite (14 pasien) dan yang tidak (31 pasien), kemudian dilakukan perbandingan lama diare antara dua kelompok. Rata-rata lama diare pada pasien yang mendapatkan dioctahedral smectite lebih pendek daripada yang tidak, dan lama diare ini berbeda secara bermakna $(p<0,05)$. Dioctahedral smectite dapat menurunkan durasi diare pada anak dengan diare kronik.
\end{abstract}

Kata kunci : anak, diare kronik, dioctahedral smectite.

\section{DIOCTAHEDRAL SMECTITE SHORTENED THE DURATION OF CHRONIC DIARRHOEA IN CHILDREN}

\begin{abstract}
Chronic diarrhea is one of a common gastrointestinal problem affecting 3 to $20 \%$ in children under 5 years. It defined as a decrease in stool consistency for more than 14 days. Dioctahedral smectite is an adsorbent widely used for the treatment of diarrhea in children. It can adsorbs toxins, bacteria, and rotavirus, preventing their adherence to intestinal membranes. Dioctahedral smectite strengthens the mucosal barrier, and in the absence of mucus, it prevents its disruption. The aim of this study was to investigate the clinical effectiveness of dioctahedral smectite in shortening chronic diarrhea in children. One hundred and forty five children who were diagnosed as chronic diarrhea in Dr. Saiful Anwar General Hospital Malang during Januari 2012 - December 2016, were investigated. Only 45 records were eligible for this study. Fourteen patients received dioctahedral smectite and 31 patient were not. The duration of diarrhea between two groups was compared. The mean duration of diarrhea was shorter in patients who got dioctahedral smectite than who did not, and it was significanty different $(p<0.05)$. Dioctahedral smectite shortened the duration of dhiarrhea in children with chronic diarhhea.
\end{abstract}

Keywords: chronic diarrhea, dioctahedral smectite, pediatic

* Laboratorium/SMF IImu Kesehatan Anak Fakultas Kedokteran Universitas Brawijaya-RSUD Dr. Saiful Anwar, Malang

凶E-mail: satrio_wibowo@ub.ac.id 


\section{Pendahuluan}

Diare persisten/kronik mencakup 3-20 $\%$ dari seluruh episode diare pada balita. Insiden diare persisten di beberapa negara berkembang berkisar antara $7-15 \%$ setiap tahun dan menyebabkan kematian sebesar $36-54 \%$ dari seluruh kematian akibat diare.1,2 Di Indonesia, prevalensi diare persisten/kronik sebesar $0,1 \%$ dengan angka kejadian tertinggi pada anak - anak berusia 6 - 11 bulan.,3 Diare kronik adalah buang air besar dengan frekuensi yang meningkat dengan konsistensi tinja lebih lembek atau cair dan berlangsung dalam waktu lebih dari 2 minggu. Sebagian ahli lain berpendapat bahwa diare kronis merupakan kategori luas kondisi diare dengan etiologi non infeksius yang berlangsung lebih dari 2 minggu, dan ada lagi yang disebut dengan diare persisten yaitu diare yang berlangsung lebih dari 2 minggu dengan penyebab infeksius. ${ }^{1,4}$

Secara umum penatalaksanaan diare kronik ditujukan untuk mencegah dan mengobati dehidrasi, gangguan keseimbangan elektrolit, malabsorpsi akibat kerusakan mukosa usus, penyebab diare yang spesifik, gangguan giz serta mengobati penyakit penyerta ${ }^{5}$. Dioctahedral smectite (diosmektit) adalah mineral tanah liat yang bersifat absorben yang dapat digunakan untuk pengobatan diare ${ }^{6}$. Diosmektit terbukti memiliki beberapa sifat farmakologis yang bermanfaat untuk diare. Diosmektit dapat menyerap racun patogen, garam empedu, dan lisoitin, termasuk enteropatogen seperti E.coli, rotavirus, dan coronavirus serta racun bakteri seperti enterotoksin clostridium difficile A, B, C dan C.perfringens enterotoksin. ${ }^{7}$ Peneliti Edelman menyatakan karakteristik senyawa antisekretori yang ideal untuk pengobatan diare menular adalah yang memenuhi syarat : menghambat sekresi cairan atau merangsang penyerapan cairan oleh mukosa usus, serangan dari tindakan dalam hitungan menit, efek konstipasi yang terbatas, indeks terapeutik yang tinggi, gangguan dengan pemulihan fungsi usus lokal, efek sistem saraf pusat minimal, potensi penyalahgunaan rendah, dan biaya rendah. ${ }^{8}$ Syarat ini dapat dijumpai pada diosmektit, baik dari segi khasiat maupun keamanan. Penelitian ini bertujuan untuk meneliti manfaat penggunaan diosmektit terhadap lama / durasi diare kronis pada anak.

\section{Bahan dan Metode}

\section{Desain Penelitian}

Penelitian bersifat deskriptif dan pengambilan data secara retrospektif. Data diperoleh dari rekam medik pasien anak rawat inap dengan diagnosis diare kronik yang diambil selama 5 tahun dari periode Januari 2012 sampai Desember 2016 di RSUD Dr. Saiful Anwar Malang. Penelitian ini telah mendapatkan persetujuan layak etik dari Komisi Etik RSUD. Dr. Saiful Anwar Malang dengan nomor: 434/EC/KEPK/12/2017.

\section{Populasi Penelitian}

Populasi dalam penelitian ini adalah pasien anak rawat inap yang terdiagnosis diare kronik di RSUD Dr. Saiful Anwar Malang. Populasi diambil dari bulan Januari 2012 sampai Desember 2016 dan memenuhi kriteria inklusi.

\section{Sampel Penelitian}

Jumlah sampel yang diambil dari populasi menggunakan metode pengambilan sampel secara purposive.

\section{Kriteria Inklusi dan Eksklusi \\ Kriteria inklusi pada penelitian ini adalah pasien anak usia 1 bulan sampai 14 tahun yang terdiagnosis penyakit diare kronik, yang dirawat inap di RSUD Dr. Saiful Anwar Malang, antara bulan Januari 2012}


sampai Desember 2016. Pasien mendapat terapi standar berupa cairan dan zink. Kriteria eksklusi adalah Diare kronik dengan hasil feses lengkap didapatkan darah dan atau parasit. Diare kronik dengan sakit berat atau penyulit seperti HIVIAIDS, diare berdarah, kejang dengan penurunan kesadaran.

\section{Definisi Operasional}

Definisi operasional adalah pasien anak usia 1 bulan sampai 14 tahun yang terdiagnosis penyakit diare kronik, yang dirawat inap di RSUD Dr. Saiful Anwar Malang. Pasien mengalami diare kronik yaitu buang air besar dengan frekuensi yang meningkat dengan konsistensi tinja lebih lembek atau cair dan berlangsung dalam waktu lebih dari 2 minggu.

\section{Teknik Pengumpulan Data}

Data yang dikumpulkan adalah data sekunderyang sesuai dengan kriteria inklusi dan eksklusi dari catatan rekam medik pasien di RSUD Saiful Anwar Malang, data yang diambil meliputi :1. Karakteristik pasien, meliputi usia, jenis kelamin; 2. Diagnosis; 3 . Jenis obat yang digunakan yaitu dibedakan menjadi 2 kelompok, kelompok pasien yang mendapatkan obat diosmektit dan tidak; 4 . Lama diare.

\section{Teknik Analisis Data}

Data yang diperoleh diolah secara deskriptif berdasarkan karakteristik pasien dan jenis obatyang digunakan. Berdasarkan jenis obat yang digunakan pasien diare kronik dibedakan menjadi 2 kelompok, yaitu kelompok pasien yang mendapatkan obat diosmektit dan tidak. Selanjutnya lama diare kelompok pasien yang mendapatkan obat diosmektit dan tidak dibandingkan menggunakan chi-square test.

\section{Hasil}

Jumlah total populasi terjangkau dalam penelitian ini adalah pasien anak rawat inap yang terdiagnosis menderita diare kronik, antara bulan Januari 2012 sampai Desember 2016 dan memenuhi kriteria inklusi dan eksklusi adalah 45 pasien.

Demografi pasien diare kronik:

Evaluasi berdasarkan jenis kelamin

Berdasarkan jenis kelamin, jumlah pasien diare kronik laki-laki adalah 20 orang (20/45) dan perempuan adalah 25 orang (25/45). Angka penderita diare kronik berdasarkan jenis kelamin dapat dilihatpada Tabel 1.

Tabel 1. Jumlah pasien berdasarkan jenis kelamin

\begin{tabular}{cccc}
\hline No & $\begin{array}{c}\text { Jenis } \\
\text { kelamin }\end{array}$ & $\begin{array}{c}\text { Jumlah } \\
\text { pasien }\end{array}$ & Persentase \\
\hline 1. & Laki - laki & 20 & $20 / 45$ \\
2. & Perempuan & 25 & $25 / 45$ \\
\hline & Total pasien & 45 & $45 / 45$ \\
\hline
\end{tabular}

Dari Tabel 1, diketahui bahwa pasien diare kronik pada anak terbanyak adalah perempuan, yaitu sebanyak 25/40.

\section{Evaluasi berdasarkan usia}

Populasi dalam penelitian ini adalah anak yang menderita diare kronik usia 1 bulan sampai 14 tahun dengan rata-rata usia adalah 5,6 tahun.

Evaluasi berdasarkan jenis obat yang diberikan

Berdasarkan jenis obat yang diberikan pasien diare kronik dibedakan menjadi 2 kelompok, yaitu kelompok pasien yang mendapatkan obat diosmektit dan tidak. 
Tabel 2. Jumlah pasien berdasarkan jenis obat yang diberikan

\begin{tabular}{llcc}
\hline No & \multicolumn{1}{c}{ Jenis Obat } & $\begin{array}{c}\text { Jumlah } \\
\text { pasien }\end{array}$ & Persentase \\
\hline 1. & Mendapat diosmektit & 14 & $14 / 45$ \\
2. & $\begin{array}{l}\text { Tidak mendapat } \\
\text { diosmekti }\end{array}$ & 31 & $31 / 45$ \\
\hline & Total pasien & 45 & $45 / 45$ \\
\hline
\end{tabular}

Berdasarkan Tabel 2, diketahui bahwa pasien diare kronik yang mendapatkan obat diosmektit sebanyak 14 anak dan yang tidak mendapatkan obat diosmektit sebanyak 31 anak.
Perbandingan lama diare kronik kelompok pasien yang mendapatkan obat diosmektit dan tidak

Pada Gambar 1 menunjukkan bahwa kelompok pasien dengan diare kronik yang mendapatkan obat diosmektit memiliki lama diare yang jauh lebih pendek $(14,85 \pm 0,97$ hari) dibandingkan kelompok pasien dengan diare kronik yang tidak mendapatkan obat diosmektit $(26,95 \pm 0,6$ hari), dengan nilai signifikansi $p<0,05$.

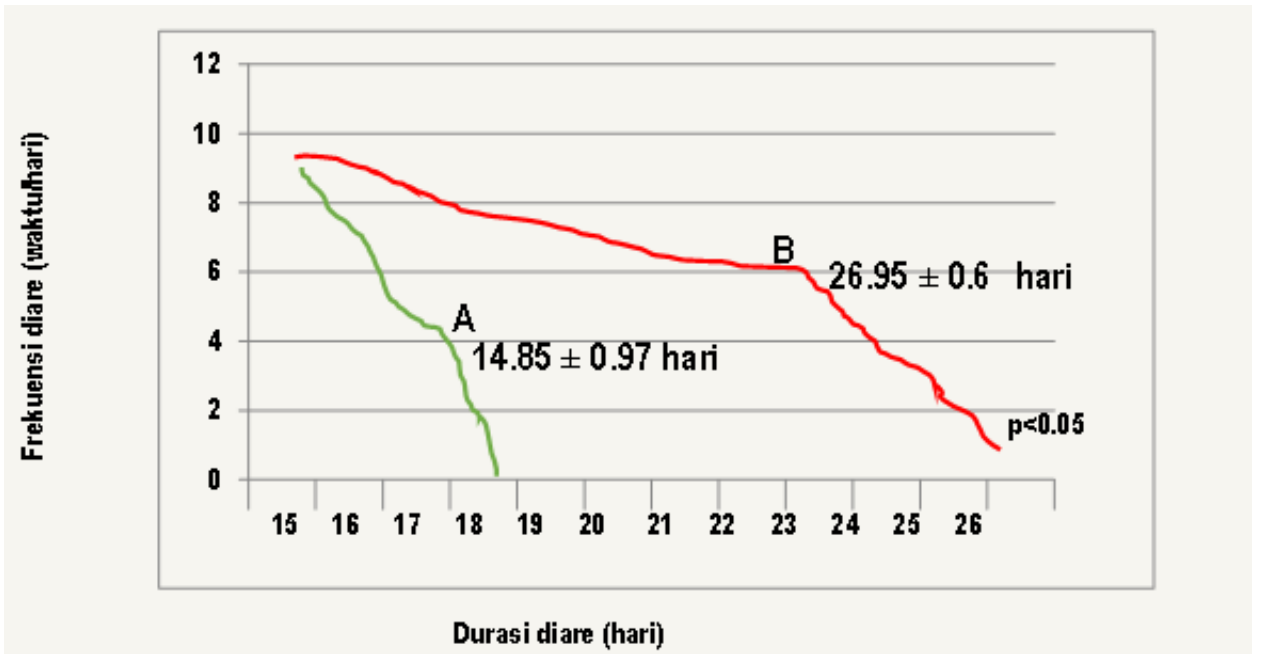

Gambar 1. Lama diare kronik pada pasien yang mendapatkan obat diosmektit (A) dan tidak mendapatkan obat diosmektit (B).

\section{Pembahasan}

Diare kronik masih merupakan salah satu masalah saluran cerna tersering pada anak. Sekitar $3-20 \%$ anak dengan diare mengalami pemanjangan durasi diare hingga lebih dari 2 minggu. Terdapat banyak sekali penyebab diare khronis pada anak, seperti faktor infeksi, makanan, defisiensi sistem imun, keradangan saluran cerna yang non spesifik, dsb ${ }^{9,10}$. Namun demikian, upayaupaya klinis dalam mencari penyebab diare sering menemui kegagalan. Di sisi lain, diare yang masih terus berlangsung seringkali meningkatkan risiko terjadinya komplikasi akibat diare kronik itu sendiri seperti iritasi di sekitar anus, munculnya sekunder infeksi, timbulnya demam dan nyeri serta menambah beban masalah sosial lain seperti meningkatnya kekhawatiran orang tua, bertambah panjangnya durasi perawatan, semakin tingginya biaya pengobatan dan secara menurunnya kualitas hidup anak, karena stress, tidak dapat bermain atau sekolah, dll. Untuk itu, pada diare kronik dengan dugaan penyebab yang ringan, tidak membahayakan dan tidak disertai dengan komplikasi yang berat, sering dipertimbangkan penggunaan zat adsorben seperti dioctahedral smectite.. 
Dioctahedral smectite (diosmektit) merupakan mineral tanah liat yang memiliki sifat menyerap cairan ${ }^{6}$. Diosmektit terbukti memiliki beberapa sifat farmakologis yang bermanfaat untuk diare karena menyerap racun patogen, garam empedu, dan lisoitin, termasuk enteropatogen. Namun demikian, penelitian tentang penggunaan zatini secara klinis masih sangat terbatas, sehingga perlu dilakukan upaya-upaya untuk mengetahui manfaat dari pemberian zat ini.

Dalam penelitian ini didapatkan 45 catatan medis anak dengan diare kronik yang memenuhi kriteria inklusi untuk dilakukan retrospektit kohort. Selanjutnya data tersebut dibagi menjadi 2 kelompok yaitu data dari anak yang mendapatkan diosmektit $(n=14)$ dan yang tidak mendapatkan diosmektit $(n=31)$. Terdapat perbedaan durasi lama rawat di rumah sakit antara pasien dengan diare kronik yang mendapatkan obat diosmektit $(14,85 \pm 0,97$ hari) dibandingkan kelompok pasien dengan diare kronik yang tidak mendapatkan obat diosmektit $(26,95 \pm 0,6$ hari), dengan nilai signifikansi $p<0,05$. Sehingga, dalam penelitian ini, pemberian obat dioctahedral terbukti memperpendek duraasi diare pada kasus anak-anak dengan diare kronik.

Penelitian ini sesuai dengan beberapa penelitian terdahulu yang menyatakan bahwa diosmektit dapat memperpendek durasi diare akut dan menurunkan volume tinja. Dupont et al (2009) melalui dua penelitian di Peru ( $n=300$ an) dan Malaysia ( $\mathrm{n}=302$ anak) menyatakan bahwa rerata volume tinja pada kelompok diosmektit adalah $94.5 \pm 74.4 \mathrm{~g} / \mathrm{kg}$ dan kelompok kontrol $104.1 \pm 94.2 \mathrm{~g} / \mathrm{kg}$. Sedangkan penelitian yang dilakukan oleh Faouzi et al (2011) waktu penyembuhan menggunakan diosmektit53,8 jam (kisaran(3.7-167.3)) $(n=$ 166) dan 69 jam (kisaran(2.2-165.2)) $(\mathrm{n}=$ 163) menggunakan placebo 8,11 .

Dalam sebuah tinjauan sistematis yang diterbitkan pada tahun 2006,
Szajewska dkk, mengevaluasi sembilan percobaan terkontrol acak termasuk 1.238 peserta dengan meta analisis. semua penelitian ini dilakukan pada anak di bawah lima tahun dan mayoritas pada bayi di bawah dua tahun. Kriteria utama metaanalisis adalah durasi diare. Melibatkan 1096 pasien temuan dari keenam studi ini menunjukkan penurunan yang signifikan dalam durasi diare pada pasien mendapat diosmektit. Perbedaan rata-rata standart dalam durasi diare adalah 22,7 jam $(95 \% \mathrm{Cl}$ : $-24,8$ sampai 20,6 ) yang mendukung kelompok diosmektit + ORS, dibandingkan dengan kelompok ORS saja. Perbedaan ini signifikan secara statistik $(P<0,0001)$ dan relevan secara klinis. meta-analisis juga mengevaluasi proporsi pasien yang sembuh setelah tiga dan lima hari pengobatan, yang dapat dievaluasi dari empat penelitian. Semua penelitian konsisten, menunjukkan tingkat pemulihan yang lebih tinggi pada pasien yang diobati dengan diosmektit. Dengan menggunakan model efek acak, kesempatan relatif pemuliham adalah 1,55 (95\% Cl: 1,29 - 1,87) pada hari ke 3 dan 1,19; $\left(95 \%\right.$ Ci: 0,93-1,53) pada hari ke $5 .{ }^{8}$

Adapun kelemahan dari penelitian ini adalah : (1) retrospektif kohort membuka peluang terjadinya bias memori dari ibu penderita mengenai awal dan lama waktu diare, (2) jumlah sampel yang sedikit, (3) saat pemberian diosmektit terhadap awal diare yang tidak sama, (4) kausa penyebab diare yang beragam.

\section{Kesimpulan}

Pada penelitian ini pemberian diosmektit dapat mengurangi lama waktu diare. Namun demikian, masih dibutuhkan penelitian lebih lanjut dengan metode penelitian yang lebih baik untuk mendapatkan hasil yang lebih valid. 


\section{Daftar Pustaka}

1. Lee KS, Kang DS, Yu J, Chang YP, and Park WS. How to Do in Persistent Diarrhea of Children?: Concepts and Treatments of Chronic Diarrhea. Pediatric Gastroenterology, Hepatology \& Nutrition. 2012; 15(4):229-236.

2. Suraatmaja S. Diare Kronik dalam Kapita Selekta Gastroenterologi Anak. Lab/SMF IImu Kesehatan Anak FK UNUD/RS Sanglah. Cetakan ketiga. Sagung Seto. Denpasar. 2010.

3. Soenarto Y. Diare kronis dan Diare Persisten dalam Buku Ajar Gastroenterologi-Hepatologi. Jilid I. Cetakan ketiga. UKK GastroenterologiHepatologi. IDAl. Jakarta. 2012.

4. Matthai J. Chronic and Persistent Diarrhea in Infants and Young Children: Status Statement. Pediatric Gastroenterology chapter. Indian Academy of Pediatrics. 2011; 48.

5. Juffrie M, Mulyani NS. Diare Persisten dalam Modul Pelatihan Diare. Edisi pertama. UKK GastroenterologiHepatologi. IDAl. Jakarta. 2008.

6. Szajewska H, Dzjechciarz P, Mrukowicz J. Meta-analysis: Smectite in the treatment of acute infectiousdiarrhoea in children. Aliment Pharmacol Ther. 2006; 23: 217-227.

7. Faure C. Role of Antidiarrhoeal Drugs as Adjunctive Therapies for Acute Diarrhoea in Children. International Journal of Pediatrics. 2013;612403.

8. Dupont C, Foo JLK, Garnier P, et al. Oral Diosmectite Reduces Stool Output and Diarrhea duration in Children With Acute Watery Diarrhea. Clinical Gastroenterology and Hepatology. 2009; 7:456-462.

9. Evans, J. 2011. Protracted Diarrhea dalam Pediatric Gastrointestinal and Liver Disease. Catakan keempat. Elsevier Saunders . USA 2011; 350-359

10. Dawn ER. 2010. Diarrhea dalam Pediatric Practice : Gastroenterology. 2010; 41-54

11. Faouz K, Mrad Al, Azzouz M, et al. Efficacy of Diosmectite (Smecta) in the Treatment of Acute Watery Diarrhoea in Adults : A Multicentre, Randomized, Double-Blind, Placebo-Controlled, Parallel Group Study. Gastroenterology Research and Practice. 2011; 1-8 